\title{
BLENDED LEARNING IMPLEMENTATION IN TEACHING BIOLOGY IN UKRAINIAN SECONDARY SCHOOLS
}

\section{Kotienieva Iryna ${ }^{1}$ Kurlishchuk Inna ${ }^{2}$}

DOI: https://doi.org/10.30525/978-9934-571-89-3_18

Nowadays lots of modern educational technology tools are integrated to the educational process of a new Ukrainian school system. It is obviously that computers, digital technologies, multimedia, interactive boards, smartphones and tablets can help students actively engage in learning process and develop their cognitive, critical thinking and problem solving skills, improve their ability to manage emotions, cooperate and communicate not only with other secondary students but with school staff, teachers, coevals, and to strive for an improvement as well. These outcomes are fully consistent with the goal of Ukrainian state education that is described in the Law of Ukraine On Education (2017): "A goal of the education is comprehensive development of the human being as a personality and as the supreme value of the society, development of its talents, intellectual, creative and physical abilities, formation of values and competences necessary for successful self-realization, raising responsible citizens capable to make a conscious choice and channel their activities for the good of other people and the society, and enriching the intellectual, economic,

\footnotetext{
${ }^{1}$ Luhansk Taras Shevchenko National University, Ukraine

${ }^{2}$ Luhansk Taras Shevchenko National University, Ukraine 
creative, cultural potential of the Ukrainian people on this basis, improving an educational level of the people in order to ensure Ukraine's sustainable development and its European choice" [4].

Educators often mix traditional teaching technologies and methods with online activities for the efficient educational models' creation and that's why many new education technologies that are based on media and digital tools are widely spread in the system of education in Ukraine. Among them, there is blended learning that combines knowledge, pedagogical and social experience of teachers with the power of technology to create a student-oriented dynamic learning environment. It is necessary to emphasize that a student-oriented dynamic learning environment is characterized by student activity; it is designed to meet the needs of all students in the group, students are engaged in the learning process development, and teachers discover and support each student's individuality and personality. Thus, it helps students to reach their potential, improve their creativity as well as successfully achieve the common academic goals. Blended learning offers strong opportunities for learning and engagement in life.

In the world pedagogical theory and practice, a considerable number of researches on the issue of blended learning have been conducted (Michelle M. Driscoll, John Bersin, Curt Bonk, Charles Graham, Michael Christie, Ramón Garrote Jurado, Gina Saliba, Lynn Jeffrey, Sue Greener, Artem Soloveichuk and others). Today the problem of blended learning technology in Ukrainian educational system is in the focus of pedagogical researches as well (T. Bondarenko, V. Kukharenko, L. Shapran, S. Berezenska, K. Buhaichuk, O. Rybalko and others). Nevertheless, a number of aspects of blended learning are still uncovered, in particular the role of blended learning in teaching Biology at secondary schools.

The purpose of the paper is to analyze the practice of using blended learning as a modern education technology in teaching Biology at Ukrainian secondary schools by researching Kyiv state education institutions' experience. According to this purpose the following tasks are determined: 1) to conduct a theoretical analysis on the issue studied; 2) to provide the Biology educators' questionnaire on the problem of identifying their attitudes toward blended learning and interpret the received empirical data.

It should be stressed that blended learning is a pedagogical technology that integrates the best aspects of face-to-face and online interactions with using appropriate ICTs. Clayton M. Christiansen and Michael B. Horn (2013) defined blended learning as follows: "a formal education program in which a student learns; at least in part through online delivery of content and instruction, with some element of student control over time, place, path, and/or pace; at least in part in a supervised brick-and-mortar location away from home, and the modalities along each student's learning path within a course or subject are connected to provide an integrated learning experience" $[1$, p. 8].

According to Russell T. Osguthorpe and Charles R. Graham (2003), blended learning is a balanced way to get the maximum benefit of both face-to-face and online learning environments [3]. 
The Commonwealth of Learning (COL) (2015) defined blended learning as an approach to teaching and learning that combines different methods, technologies, and resources to improve student learning, they also emphasized the student-centered approach, offering autonomy and flexibility [2].

To sum up, blended learning is a well established modern educational technology that includes face-to-face and online or social media tools for improving teaching and class management practice and achieving better student learning outcomes in different school disciplines, in particular in teaching and learning Biology.

Biology knowledge is an essential part of the curriculum of modern Ukrainian secondary schools. As a rule, secondary pupils start to study Biology in grade 6, and continue its studying till they finish High School. Biology as a school science subject usually includes Botany, Zoology, and Human Physiology knowledge that is divided into separate sections and taught in different school years. The field of this school subject is really enormous and there is the necessity to find and use effective education technologies for its teaching and learning. To our mind, blended learning is a perfect learning strategy that can develop the secondary pupils' ability to think critically and creatively, to improve ICT literacy and problem solving skills, to help pupils' efficient online and offline communication and collaboration.

Our empirical research on the issue included the Biology teachers' questionnaire on the problem of identifying their attitudes toward blended learning, as well as determining the main benefits and problems of blended learning providing in the classroom. The sample of the study consisted of 51 Biology teachers from 17 Kyiv state secondary education institutions. The questionnaire was conducted during the academic year 2017-2018.

According to the tasks of the study we created the original questionnaire aimed at purposes of our research. It was with both closed (answers were previously determined) and open (answers were not previously determined) questions. The questionnaire starts with demographic question section. It traditionally includes questions about age, gender, job experience and professional qualifications. Demographic question section followed by the question "Have you ever used blended learning in your teaching practice?" Biology teachers were also asked how often and how long they use this technology in their classroom. Then they were asked to indicate their motivation for using blended learning. One of the tasks of the questionnaire was to generalize the topics that are the most suitable for teaching through blending learning. So the questionnaire had the questions about this problem, too. In addition, our respondents were asked about advantages of blended learning, and about the main problems of providing this modern technology into the education process of a new Ukrainian school system. Of course, teachers were asked whether they need extra information about blended learning and whether they would prefer to attend special courses on this problem. The information about the answers on the questionnaire is provided bellow.

Biology teachers widely use blended learning in their teaching practice and consider it very efficient technology. They use a wide variety of types of blended learning technologies such as lab rotation blended learning, project-based blended 
learning, self-directed blended learning, flex blended learning, individual rotation blended learning, inside-out blended learning, outside-in blended learning and others. At the same time, they are really interested in attending the additional courses on the providing blended learning into the education process of a modern school.

Among the main benefits of blended learning teachers named such benefits as: 1) to support planning and creating class content; 2) to provide students with an opportunity to individual work; 3 ) to broaden the spaces of teaching and learning; 4) to support efficient classroom management; 5) to help in student engagement into education process; 6) to organize multiple forms of feedback; 7) to motivate students for using different sources of information and interact in different ways with teachers, each other, society, etc.

Among the main problems of providing blended learning in education process are: 1) schools are not able to provide students with all necessary facilities like computer labs, internet connection, etc.; 2) teachers are not trained for integrated classroom, they are not ready to use modern digital technologies; 3) students don't have access to computers at home; 4) lack of parents' support.

In responses to a question about how using blended learning has affected their teaching success, they indicated that their professional achievements are raised by using this technology as well as the outcomes of their students.

Blended learning is a modern trend in education environment of a new Ukrainian school. The importance of it using is gradually increasing in Biology teaching. Blended learning gives teachers the ability to create proper pre - and post - class activities as well as collaborative and integrative classroom learning environment to involve their students in joyful, challenging and creative education process. Blended learning technologies through combination of direct teaching and e-learning can also personalize and update teaching Biology, and strengthen teachers' professionalism and students' self-motivation for successful studying.

\section{References:}

1. Christiansen, C., Horn, M., \& Staker, H. (2013). Is K-12 blended leaning disruptive? An introduction to the theory of hybrids. Clayton Christensen's Institute for disruptive innovation.

2. Commonwealth of Learning. (2015). Open and distance learning: Key terms and definitions. Retrieved from: http://oasis.col.org/bitstream/handle/11599/829/Definitions_ODL\%20key\%20 terms_20150522.pdf?sequence $=4$

3. Osguthorpe, R.T. \& Graham, C.R. (2003). Blended Learning Environments: Definitions and Directions. Quarterly Review of Distance Education, 4(3), 227-234. Retrieved February 20, 2019 from https://www.learntechlib.org/p/97576/

4. The Law of Ukraine on Education. (2017). Retrieved February 20, 2019 from: https://www.venice.coe.int/webforms/documents/default.aspx?pdffile=CDL-REF(2017)047e 